\title{
Effect of shot PEENING on Water Vapor Oxidation Resistance of Austenitic Stainless Steel TP347H
}

\author{
Rui Chen \\ HUADIAN ELECTRIC POWER RESEARCH \\ INSTITUTE, Hangzhou, China \\ rui-chen@chder.com
}

\begin{abstract}
In order to study the effect of shot peening on water vapor oxidation resistance of austenitic stainless steel TP347H, spare reheater tube of a certain power plant is made into the experimental sample, and part of the samples have been shot blasted, the experimental samples are used to do the contrast test of high temperature water vapor oxidation using a laboratory high temperature steam oxidation device. The oxidation kinetics equations are obtained by oxidation kinetics experiments, results show that in the high temperature steam environment of $800{ }^{\circ} \mathrm{C}$ within $80 \mathrm{~h}$, oxidation kinetics equation of TP347H steel comply with the laws of parabola. oxidation membrane surface and cross-section was analyzed by using SEM, EDX and GIXRD and the results show that shot peening changes the oxide layer of phase composition and the structure of oxidation layer, and significantly improve the oxidation resistance of TP347H steel.
\end{abstract}

Keywords--Shot peening; ТP347H; oxidation; water vapor

\section{INTRODUCTION}

In recent years, in order to respond to the country's energy utilization and energy saving policies, Efficient (Ultra) supercritical units have been put into operation, the improvement of unit parameters makes steam oxidation of boiler heating surface temperature increasingly prominent. The oxide films on the inner wall of four boiler tubes (water wall tubes, superheater tubes, reheater tubes, economizer tubes) peel off and block airflow channel causing local overheating tube explosion incidents happen occasionally, and Oxide membrane particles also produce erosion for the steam room components causing abnormal corrosion and wear of turbine blades, nozzles, and impeller bulkhead, which has great threat for the power plant's safety,

\author{
Guikuan He \\ HUADIAN ELECTRIC POWER RESEARCH \\ INSTITUTE, Hangzhou, China \\ guikuan-he@chder.com
}

reliability and economic operation. ${ }^{[1-7]}$ For this reason, companies like Japan NKK firstly proposed that carrying out shot peening and fine grain processing to the inner wall of austenitic stainless steel pipe improve the water vapor oxidation resistance of inner wall. ${ }^{[8-11]}$

$\mathrm{TP} 347 \mathrm{H}$ is the superheater and reheater tubes materials commonly used by power plant. In the experiment, the samples were been shot blasted, and the experiment was carried out through the homemade laboratory high temperature steam oxidation device. After experiment, morphology and composition analysis and research to the oxidized samples been shot blasted and without were carried out. The experiment verifies that shot peening can significantly improve the oxidation resistance of inner wall of TP347H steel pipe.

\section{EXPERIMENTAL MATERIALS AND METHOD}

\section{A. Sample preparation}

The TP347H steel pipe used to the experiment is reheater spare tube of a certain power plant at Zhejiang, the Chemical Composition shown in Table 1, complies with the rules of GB5310-1995 and ASMESA213. Using wire-electrode cutting got a size of $8 \mathrm{~mm} \times 8 \mathrm{~mm} \times 4 \mathrm{~mm}$ cuboid specimens, which were dried in the drying dish after grinded, polished and cleaned, and divided into two equal portions. One of the portion were been shot blasted using pressure of $0.5 \mathrm{Mpa}$ and a 60 mesh quartz glass beads. All samples were weighed using Optical Reading Analytical Balances, then subjected to steam oxidation test

TABLE I CHEMICAL COMPOSITIONS OF TP347H STEEL

\begin{tabular}{lccccccccc}
\hline \multicolumn{1}{c}{ Element } & C & Mn & P & S & Si & Cr & Ni & & \\
\hline Test values & 0.07 & 1.74 & 0.02 & 0.008 & 0.47 & 17.78 & 10.13 & 0.83 & \\
\hline
\end{tabular}

\section{B. Experimental device}

The self-inventive laboratory high temperature steam oxidation device shown in figure 1, has simple structure, high precision, low cost, high degree of automation. The working temperature of tube furnace used is in the range $0-1300{ }^{\circ} \mathrm{C}$, controlled by electric temperature controller produced by Japan and single phase SCR power controller, and the error of temperature control is estimated to be \pm $1{ }^{\circ} \mathrm{C}$, Precise temperature control can ensure the stability of the temperature of the reaction zone. The experiments were been deoxidized using the deionized water and purging with nitrogen, the oxygen content in the water could be accurately measured using the oxygen analyzer. Float level controller enables to automatically water from storage bottle to the reaction flask. Because the experimental time is short, and in order to preferably simulate actual working conditions of plants, the rate of oxidation was accelerated ,the experimental temperature was $800{ }^{\circ} \mathrm{C}$ and 
the armored digital thermocouple installed could accurately measure the temperature of the reaction zone. The experimental time node were $10,20,40,60,80 \mathrm{~h}$. To each time node, the oxidized samples been shot blasted and without were respectively removed and marked, and the samples were weighed in the optical reading dry analytical balance after cooling and drying, then the oxidation kinetics curves were established. The morphology and composition of oxide layer of oxidized samples was analysed adopting FEI Quanta 400 scanning electron microscope made in US and OXFORD INCA X-ray energy dispersive spectroscopy.

\section{RESUlts AND ANALYSIS}

\section{A. Oxidation kinetics}

According to (1), the gain in weight of unit surface area of oxidized sample can be calculated, wherein $\mathrm{Wt}$ is the sample's weight at the time of t,Wa is the sample's initial weight,and $\mathrm{S}$ is the the surface area.

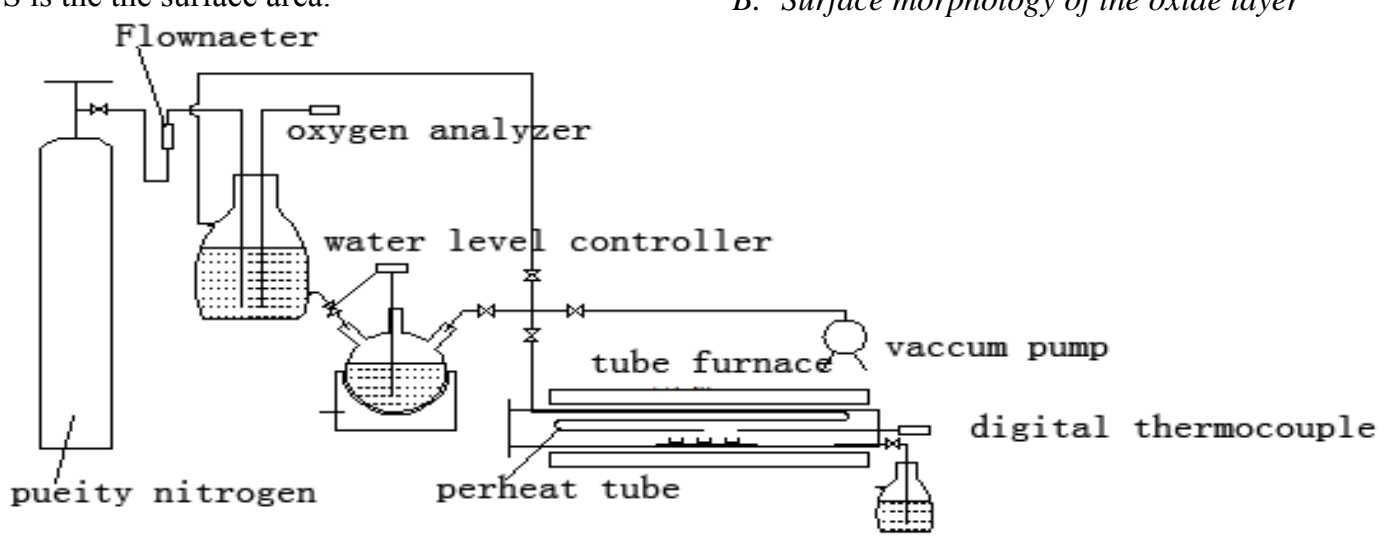

Figure 1. Sketch of high temperature steam oxidation device

$$
\Delta \mathrm{W}=\left(\mathrm{W}_{\mathrm{t}}-\mathrm{W}_{\mathrm{a}}\right) / \mathrm{S} \times 10^{6}
$$

By calculating the increase of weight of unit surface area at each time point, the oxidation kinetics curves can be drawn out. The figure 2 is oxidation kinetics curves that the samples of TP347H steel been shot blasted and without were oxidized to $80 \mathrm{~h}$ in the steam of $800^{\circ} \mathrm{C}$.

Using Origin software fitted the experimental data points obtaining oxidation kinetics equation. The oxidation kinetics equation of TP347H steel been shot blasted is $\mathrm{y}=2.3376 \mathrm{t}^{0.5364}$, and the oxidation kinetics equation of TP347H steel without been shot blasted is $y=4.703 \mathrm{t}^{0.4383}$,it can be seen that the oxidation kinetics curves comply with the laws of parabola. Contrasting the rate of oxidization gain in weight of samples been shot blasted with the sample without been shot blasted, which shows that shot peening significantly improves the oxidation resistance of steel TP347H

\section{B. Surface morphology of the oxide layer}

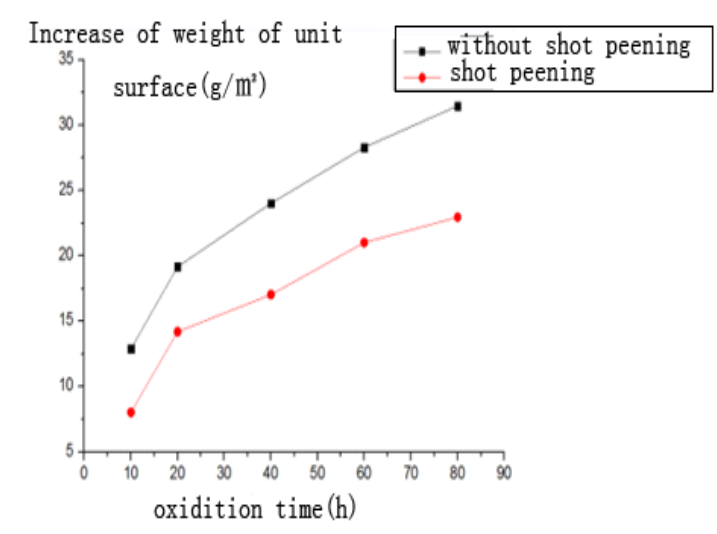

Fig ure 2. The oxidation kinetics curves of TP347H steel been shot blasted and without at the temperature of $800^{\circ} \mathrm{C}$

Figure 3 is the Surface morphology of the oxide layer of TP347H steel been shot blasted and without. the sample's surface of TP347H steel without been shot blasted is gray-black, which is an oxide of Fe by XRD analysis results; the sample's surface of TP34H and without. the sample's surface of TP347H steel without been shot blasted is gray-black, which is an oxide of Fe by XRD gray-black, which is an oxide of $\mathrm{Fe}$ by XRD analysis results; the sample's surface of TP347H steel been shot blasted is light green, which shows that the oxides of surface are rich in $\mathrm{Cr}$. The surface morphology of TP347H sample without been shot blasted is granular (shown in figure 3a), and the surface is loose; The surface of TP347H sample been shot blasted reserves the "ripple" caused by shot peening, and is more dense. It shows that the more compact the better oxidation resistance, indicating that the TP347Hsteel been shot blasted has better oxidation resistance. 


\section{Phase analysis of the oxide layer}

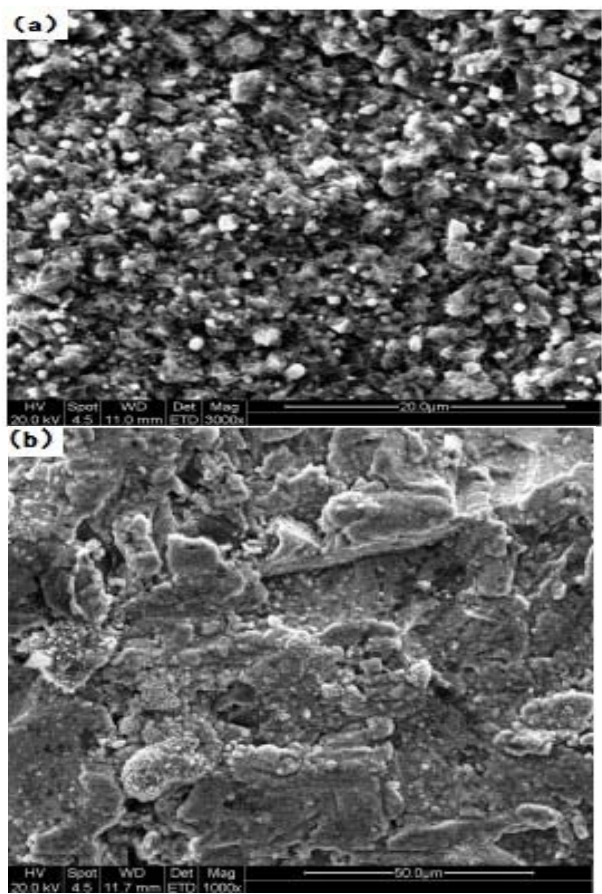

Figure 3. The Surface morphology of the oxide layer of TP347H steel been shot blasted(b) and without(a) which was oxidized to $80 \mathrm{~h}$ at $800^{\circ} \mathrm{C}$

Figure 4 is the XRD patterns of the oxide layer of $\mathrm{TP} 347 \mathrm{H}$ steel been shot blasted and without which was oxidized to $80 \mathrm{~h}$ at $800^{\circ} \mathrm{C}$.In order to reduce the diffraction intensity of matrix, the incident angle was $2^{\circ}$ using grazing incidence method. The conclusions obtained by comparing standard PDF card are as follows: the oxide layer of TP347H steel sample without been shot blasted is mainly (Fe, Cr) $3 \mathrm{O} 4$ of spinel structure and an amount of oxide of Fe. The oxide layer of sample been shot blasted is mainly $\mathrm{Cr}_{2} \mathrm{O}_{3}$ and $(\mathrm{Fe}, \mathrm{Cr})_{3} \mathrm{O}_{4}$ of spinel structure.

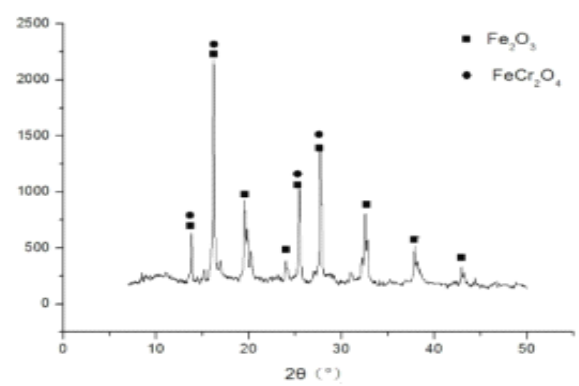

(a)

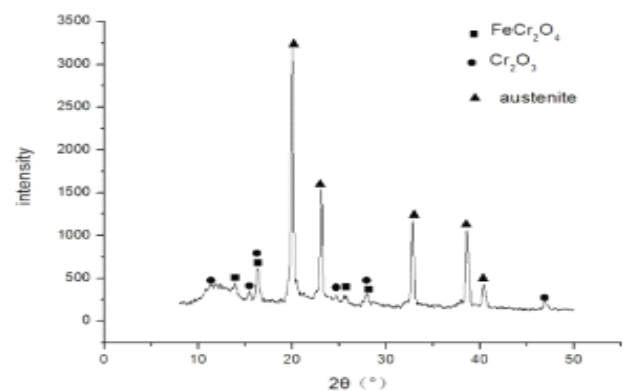

(b)

Figure 4. The XRD patterns of the oxide layer of TP347H steel been shot blasted(b) and without(a) which was oxidized to $80 \mathrm{~h}$ at $800^{\circ} \mathrm{C}$

\section{Cross-sectional morphology of the oxide layer}

Figure 5 is the Cross-sectional morphology of oxide layer of TP347H steel been shot blasted and without which was oxidized to $80 \mathrm{~h}$ at $800^{\circ} \mathrm{C}$. The sample without been shot blasted has been oxidized, the oxide layer has a double oxide structure, and the obvious cracks and holes can be observed; the sample been shot blasted has been oxidized, the oxide layer is a single structure, dense solid, and no stratification.

\section{E. Analysis of cross-Sectional components of oxide layer}

Figure 6 is the EDS dot maps of the cross-section of TP347H steel been shot blasted and without which was oxidized to $80 \mathrm{~h}$ at $800^{\circ} \mathrm{C}$, the percentage content of element of each EDS point is shown in table 2、3. It can be seen from Table 2, the content of $\mathrm{Cr}$ and $\mathrm{Ni}$ is less, $\mathrm{Fe}$ and $\mathrm{O}$ is high in the outer oxide layer of TP347H steel without been shot blasted, the outer layer is mainly the oxide of $\mathrm{Fe}$, the inner contains higher $\mathrm{Cr} 、 \mathrm{Fe} 、 \mathrm{O}$; the content of $\mathrm{Cr}$ is highest in the outermost layer, $\mathrm{Cr}$ depleted zone is not observed, the content of $\mathrm{Cr}$, Ni element is more uniform, and the element having greater mutation is also not observed. Through the Distribution of elements and The results of surface diffraction, it can be more sure that the oxide layer been shot blasted is mainly the oxide by the composition of $\mathrm{Cr}$ and $\mathrm{Fe}$.

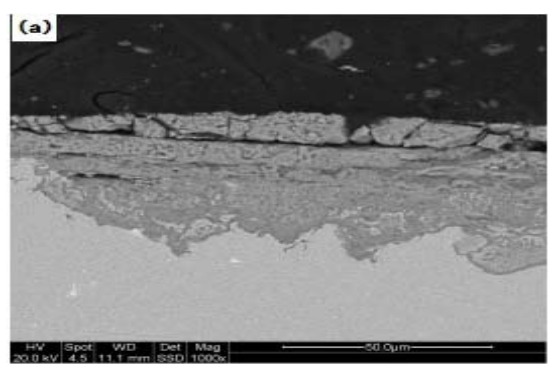




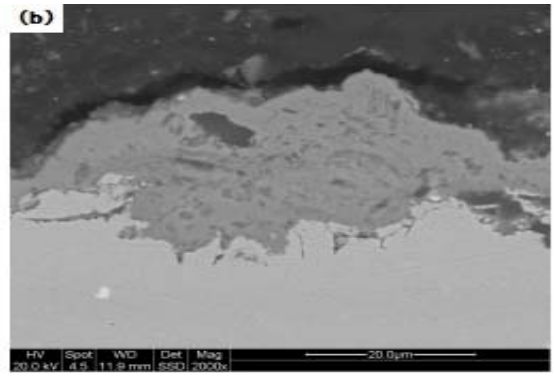

Figure 5. The Cross-sectional morphology of oxide layer of TP347H steel been shot blasted (b)And without (a) Which was oxidized to $80 \mathrm{~h}$ at $800^{\circ} \mathrm{C}$
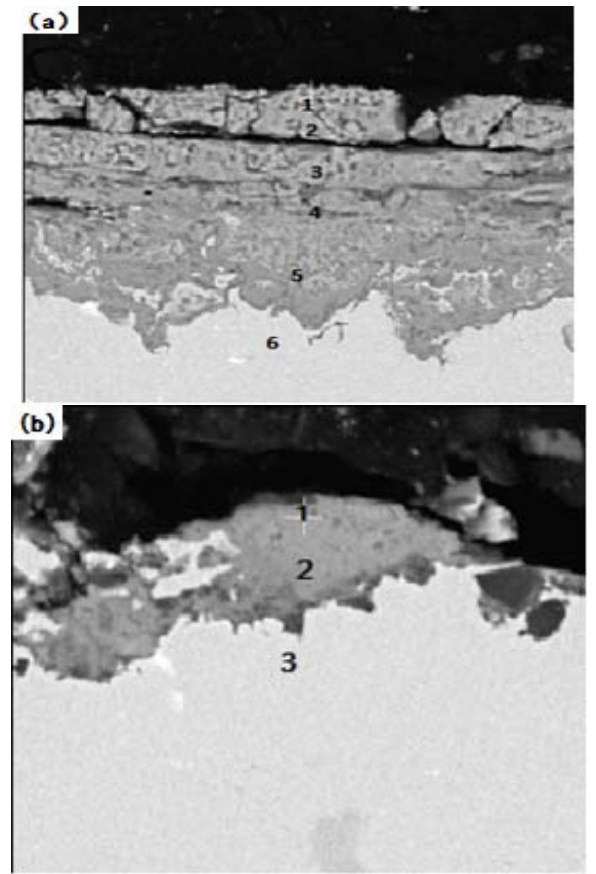

Figure 6. The EDS dot maps of the cross-section of TP347H steel been shot blasted (b)and without (a)which was oxidized to $80 \mathrm{~h}$ at $800^{\circ} \mathrm{C}$

TABLE II. THE RESULTS OF EACH SPECTRUM POINT SHOWN IN FIG.6(A) $(\mathrm{AT} \%)$

\begin{tabular}{ccccc}
\hline Atlas & $\mathbf{O}$ & $\mathbf{C r}$ & $\mathbf{F e}$ & $\mathbf{N i}$ \\
\hline 1 & 62.58 & 0.64 & 36.37 & 0.41 \\
\hline 2 & 52.40 & 1.30 & 42.19 & 4.10 \\
\hline 3 & 58.57 & 1.00 & 35.15 & 5.28 \\
\hline 4 & 59.97 & 16.84 & 15.03 & 8.43 \\
\hline 5 & 57.78 & 16.98 & 11.92 & 13.32 \\
\hline 6 & & 18.88 & 69.52 & 11.60 \\
\hline
\end{tabular}

TABLE III. THE RESULTS OF EACH SPECTRUM POINT SHOWN IN FIG.6(B) $(\mathrm{AT} \%)$

\begin{tabular}{|c|c|c|c|c|}
\hline Atlas & $\mathrm{O}$ & $\mathrm{Cr}$ & $\mathrm{Fe}$ & $\mathrm{Ni}$ \\
\hline 1 & 46.72 & 19.36 & 31.11 & 2.81 \\
\hline 2 & 63.41 & 13.85 & 20.21 & 2.53 \\
\hline 3 & & 17.80 & 73.79 & 8.41 \\
\hline
\end{tabular}

\section{CONCLUSIONS}

1. In the temperature steam environment, at the high temperature of $800^{\circ} \mathrm{C}$ within $80 \mathrm{~h}$, oxidation kinetics equation of TP347H steel comply with the laws of parabola.

2.Shot peening changes the phase constituting of oxide layer of TP347H steel, greatly improve the $\mathrm{Cr}$ content of the oxide layer forming dense $\mathrm{Cr}$, $\mathrm{O}$ compound, which inhibits the formation of $\mathrm{Fe}, \mathrm{O}$ compound, significantly reducing the oxidation rate, improving the oxidation.

3. Shot peening significantly improves the oxidation resistance of TP347H steel, TP347H boiler tube wall after being shot blasted, in which the oxide layer transforms double structure into single structure, in the oxide film has no cracks and holes phenomenon, and the oxide layer is more compact.

\section{REFERENCES}

[1] Wang Jianyong, Zhang Bo, Jin Yongqiang, Zheng Zijie .Austenite steel wall Shot layer properties and antioxidant properties[J]. boiler technology,.2009,40 (2): 48-51.

[2] Zhao Hui Chuan, Tang Liying, JIA Jian-min, SUN standard, Wang Caixia, Chen Jigang.Effect of shot peening on Anti-oxidant properties of steam of S30432 boiler tubes [J] China Power .2014, 47 (4): 9-13.

[3] Wei Dongbin, Li Xiaoqiu, He Kelong, Chen Rui, Yu Tan, Xiao Wenkai .high-temperature steam oxidative tissue component analysis of TP347H steel [J] .Wuhan University.2014,47 (4): 552-556.

[4] Yue Zengwu, Li Xingeng. Research and application of shot peening to improve the oxidation resistance of austenitic heat-resistant steel [J] . Materials and Heat Treatment.2013,34 (1): 157-162.

[5] Li Xingeng, He Jiawen . The observation of shot peening improving TP304H heat-resistant steel boiler tube steam oxidation resistance application performance $[\mathrm{J}]$ Chinese Society for Corrosion and protection .2003, 23 (3): 171-174.

[6] Wright I G, Dooley R B. A review of the oxidation behavior of structural alloys in steam [J]. International Materials Reviews, 2010, 55(3):129-167.

[7] Stott F H, Wei F I. High temperature oxidation of commercial austenitic stainless steels [J]. Mater SCI Technol, 1989, 5:1140-1147

[8] Evans H E. Spallation models and their relevance to steam grown oxides [J].Materials at High Temperatures, 2005, 22(1/2):155-166

[9] Purbolaksono J, Khinani A, Rashid A Z, Ali A A, Nordin N F. Prediction of oxide scale growth in superheater and reheater tubes[J].Corrosion Science,2009(51):1022-1029

[10] Sundararajan T, Kuroda S, Kawakita J, Seal S. High temperature corrosion of nanoceria coated 9Cr-1Mo ferritic steel in air and steam[J].Surface \& Coatings Technology,2006,(201):2124-2 130.

[11] ZHANG Du-qing, LIU Guang-ming, Zhao Guo-qun, etal. Cyclic oxidation behavior of $\mathrm{Fe}-9 \mathrm{Cr}-1 \mathrm{Mo}$ steel in water vapor atmosphere [J].Journal of Central South University of Technology, 2009,16:0535-0540 